\title{
Reseñas
}

\section{Ladislao Landa (ed.), Cristóbal de Albornoz, Mesianismo y utopía en América: Perú, siglo XVI, Lima, Yolanda Carlessi, 2018, 382 pp.}

Ladislao Landa Vásquez es antropólogo formado en la Universidad Nacional Mayor de San Marcos. Discípulo y colaborador de Luis Millones, ha sacado esta última edición de los informes del clérigo Cristóbal de Albornoz, principal fuente para conocer el célebre fenómeno del Taki Unquy, y que Luis Millones dio a conocer tras encontrarlos en el Archivo General de Indias en España hace ya décadas. El libro ha sido publicado también gracias al esfuerzo de la editora Yolanda Carlessi.

El libro consiste, fundamentalmente, en la transcripción de los mencionados informes de Cristóbal de Albornoz (Cuzco, 1569; Huamanga, 1570; Cuzco, 1577; Cuzco 1584), así como la sentencia del concilio provincial de Lima a favor de este presbítero y la carta escrita por el mismo al rey de España en 1602. Landa incluye un prólogo (pp. 7-40) donde aborda el problema historiográfico del Taki Unquy cuya consideración ha sido variada: desde verlo como un fenómeno aislado de la Sierra Central del Perú hasta todo un programa de resistencia cultural de los pueblos andinos al invasor español. También analiza el autor el método de Albornoz (basado en quince preguntas que debían contestar los interrogados por el clérigo español) y la naturaleza de sus informes, para poder analizarlos adecuadamente como fuentes históricas. Landa señala acertadamente que se trata de fuentes bastante objetivas y formularias, donde el autor busca la recolección de datos sobre la realidad en la que pretende indagar.

Por último, hace notar la problemática en torno a los términos que Albornoz recoge: Taki Unquy (en la ortografía estándar actual que Landa recomienda para el quechua y que en las fuentes aparece como taqui ongoy o taquiongo) y las palabras ayra y talauso que también hacen referencia a estos cultos o ceremonias. El autor muestra cómo el término talauso deriva de una expresión quechua muy parecida en su significado a taki unquy (la enfermedad del baile). Para el término ayra propone un origen aymara que también alude a la danza y al movimiento. Por lo que vemos, el autor no busca convertir el prólogo en una introducción que pretenda recoger una síntesis de lo que sabemos al día de hoy de este fenómeno, sino que se limita a hacer un esbozo general, ofrecer la bibliografía más

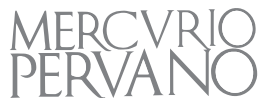


relevante y aportar las novedades que él mismo aporta, como la etimología del término ayra.

El resto del libro consiste en la transcripción de los documentos (pp. 41348). Los criterios para llevarla a cabo parecen los más adecuados. Así, se evita hacer una transcripción paleográfica que recoja todos los pormenores formales, y que llevaría a una lectura farragosa de los documentos. El autor opta por recoger los cambios de renglón y de folio y mantener la ortografía original, pero introduce a su vez las tildes y usa la mayúsculas y minúsculas conforme a las reglas actuales de la lengua española. De este modo se consigue una lectura fácil y fluida, a la vez que mantiene el estilo del español del siglo XVI.

Otro aspecto que se debe destacar de esta edición es la inclusión de índices al final del libro: toponímico, onomástico y de huacas (pp. 349-382). De esta forma, el lector tiene a su disposición una excelente edición documental que le permite buscar información de primera mano sobre este célebre movimiento andino.

Guillermo Arquero

\section{Ricardo Silva-Santisteban (2018). Escrito en el agua. Tercera edición. Lima, Alastor Editores, 570 pp.}

El poeta se encuentra en la incesante búsqueda de un lenguaje original. La musicalidad, el ritmo, la métrica, con pinceladas de sensibilidad, lo acompañarán para trastocar las fibras del espíritu del lector. A estos aspectos elementales, el creador necesita reconocer la tradición literaria, valorarla para renovarse constantemente por las sendas de la creación. Con esa aguda mirada selecciona autores imprescindibles, rescata discursos olvidados y, si la oportunidad se le da, critica con fineza los logros alcanzados por cada artista. Incluso, ese hálito poético lo lleva a traducir poemas con destreza a fin de mantener la originalidad de los versos. Pocos logran conciliar e integrar esas virtudes como el autor de Escrito en el agua.

El profesor universitario, crítico literario, poeta, editor y traductor Ricardo Silva-Santisteban ha publicado por tercera vez el mencionado libro bajo el sello de Alastor Editores. Su prosa nos invita a descubrir las melódicas y notables expresiones de la poesía universal. Esta invitación recorre y comprende la creación poética. En «Meditación acerca de la poesía y la existencia», inédito texto de una serie de treinta y tres disertaciones establece que el empleo del lenguaje constituye un componente imprescindible para el poeta, pues le permite capturar y mostrar una esencia del cosmos. Ese instinto comunicativo, producto de las lecturas heredadas, experiencias e intuiciones, lo representa y le permite trazar imágenes de notable efecto rítmico. «Los poetas logran una creación poé-

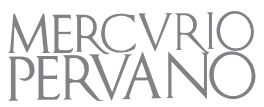

